\title{
LAND COVER AND CONSERVATION STATE OF A REGION IN THE SOUTHERN LIMIT OF THE ATLANTIC FOREST (RIVER MAQUINÉ BASIN, RIO GRANDE DO SUL, BRAZIL)
}

\author{
BECKER, F. G., ${ }^{1,3}$ IRGANG, G. V., ${ }^{1}$ HASENACK, H., ${ }^{1}$ \\ VILELLA, F. S. ${ }^{1,3}$ and VERANI, N. F. ${ }^{2}$ \\ ${ }^{1}$ Departamento de Ecologia, Universidade Federal do Rio Grande do Sul, CEP 91540-000, Porto Alegre, RS, Brazil \\ ${ }^{2}$ Departamento de Hidrobiologia, Universidade Federal de São Carlos, CEP 13565-905, São Carlos, SP, Brazil \\ ${ }^{3}$ Programa de Pós-graduação em Ecologia e Recursos Naturais, Universidade Federal de São Carlos, \\ CEP 13565-905, São Carlos, SP, Brazil \\ Correspondence to: Fernando Gertum Becker, Museu de Ciências Naturais, Fundação Zoobotânica do \\ Rio Grande do Sul, CEP 90690-000, Porto Alegre, RS, Brazil, e-mail: fgb@fzb.rs.gov.br \\ Received May 28, 2002 - Accepted December 17, 2003 - Distributed August 31, 2004
}

(With 3 figures)

\begin{abstract}
The state of conservation of Atlantic Forest in the Maquiné river basin was assessed using land cover data obtained from Landsat TM 5 satellite imagery (October 1995). The initial analysis examined the distribution of the relative areas of each land-cover type according to landscape slope classes, potential vegetation zones, and a $90 \mathrm{~m}$ riparian buffer. Land-cover classes were then regrouped into categories representing "low", "intermediate", and "high" degree of anthropogenic alteration. Results indicate that about $70 \%$ of the land cover of the Maquiné river basin has been highly altered as a consequence of replacement of natural forests by agriculture. Presently, a recovery process seems to be underway, contrasting with the historical trend towards deforestation. There are large areas of secondary vegetation in intermediate (34.8\%) and advanced successional stages (20.2\%), particularly across the range of the montane forest and of forest formations that occur at elevations higher than $800 \mathrm{~m}$ (high-montane dense ombrophilous forest and mixed ombrophilous forest). The geographical location at the southern limit of the Atlantic Forest stricto sensu and comparison of the results with data on the state of conservation of the Atlantic Forest in Rio Grande do Sul indicate that the Maquiné river basin is an important area for conservation. Some points regarding future research and conservation management are also discussed.
\end{abstract}

Key words: Atlantic Forest, secondary forest, conservation, land use.

\section{RESUMO}

Uso da terra e estado de conservação da Mata Atlântica de uma região no limite meridional da Mata Atlântica (bacia do rio Maquiné, Rio Grande do Sul, Brasil)

O estado de conservação da Mata Atlântica na bacia do rio Maquiné foi avaliado com base em dados de uso do solo. As categorias de uso do solo foram identificadas a partir de uma imagem do satélite Landsat TM 5, de outubro de 1995. Inicialmente, a análise considerou a distribuição espacial das áreas relativas de cada tipo de uso do solo em relação às classes de declividade do terreno e às zonas de vegetação potencial em uma faixa ripária de $90 \mathrm{~m}$. Posteriormente, os tipos de uso do solo foram reagrupados em categorias conforme o grau de antropização que representam: alto, intermediário e baixo. Os resultados indicam que cerca de $70 \%$ da área da bacia do rio Maquiné está, ou já foi, altamente alterada pela substituição da cobertura florestal por agricultura. Atualmente, parece haver um processo de recuperação da vegetação, uma vez que amplas áreas estão ocupadas por vegetação secundária em estádios sucessionais intermediários $(34,8 \%)$ ou avançados $(20,2 \%)$, particularmente na região da Floresta Montana e das florestas situadas acima de $800 \mathrm{~m}$ de altitude (Floresta Ombrófila Mista e Formação Alto Montana 
da Floresta Ombrófila Densa). A localização geográfica no extremo meridional da Mata Atlântica stricto sensu e a comparação com dados sobre o estado de conservação da Mata Atlântica no Rio Grande do Sul indicam que a bacia do rio Maquiné é uma importante área do ponto de vista de conservação. Alguns aspectos referentes à pesquisa científica e ao manejo também são discutidos.

Palavras-chave: Mata Atlântica, mata secundária, conservação, uso da terra.

\section{INTRODUCTION}

The Atlantic Forest is considered a global conservation hot spot because of its high biodiversity, incidence of endemics, high rate of habitat loss (only $7.5 \%$ of its original area still subsists), and anthropogenic pressure (Myers et al., 2000; CIB et al., 2000). Conservation policies and strategies have been constantly discussed and proposed for the Atlantic Forest and associated ecosystems (Câmara, 1991; Pinto et al., 1996; Marcuzzo et al., 1998; CIB et al., 2000). Determining areas for protection and in which to create ecological corridors, and providing for plant community regeneration, riparian buffers, and agroforestry systems are among the principal recommendations made so far. Another important point is that conservation units and their surrounding areas should be integrated into bioregional planning (Miller, 1997).

Assessments of regional and watershed conservation status using remotely sensed data and geographic information systems (GIS) are important in providing information for conservation planning and decision-making (Johnston, 1998; Ehlers, 1996). In this sense, identification and quantification of land cover types are particularly useful, as well as delimitation of sub-regions or zones within ecological or physical gradients (e.g., vegetation types, altitudinal zonation, and anthropogenic pressure). Regional and watershed assessments can result in maps identifying areas of interest, quantitative estimates of number and size of areas, reference locations for monitoring temporal changes, identification of information gaps (contributing to set research and management priorities), and management and conservation recommendations. Examples of such assessments in the Atlantic Forest domain are Lima et al. (1998), Pires et al. (1998), SOS Mata Atlântica et al. (1998), and Saatchi et al. (2001).

In Rio Grande do Sul State, three regions have been designated as pilot areas for implementation of an Atlantic Forest Biosphere Reserve (Marcuzzo et al., 1998). In one of these, the Litoral Norte, the
Maquiné river basin is considered particularly important for conservation of water resources (FEPAM,2000) and fishes (CIB et al., 2000). In recent years, the Maquiné region has been the object of several scientific research and extension programs (Perotto et al., 2000). The original regional forest formations were largely replaced by agriculture in the mid-twentieth century, but now large areas are found of secondary vegetation in several different successional stages.

The objective of the present work is to provide an assessment of the conservation status of natural vegetation in the river Maquiné basin. Land cover and physiographic data were used to describe the conservation state in 1995 as a basis for future comparisons. The specific aims were: 1) to estimate the degree of alteration in relation to potential vegetation zones; 2 ) to describe the spatial pattern of land use/cover with respect to different slopes, vegetation formations, and riparian buffer; and 3) to discuss various topics related to conservation, restoration, and research needs relating to the Maquiné river basin.

\section{Study area}

The Maquiné river basin is situated in northeastern Rio Grande do Sul, Brazil, approximately between $51^{\circ} 21^{\prime}-50^{\circ} 05^{\prime} \mathrm{W}$ and $29^{\circ} 20^{\prime}-29^{\circ} 50^{\prime} \mathrm{S}$. With an area of $550.5 \mathrm{~km}^{2}$, the basin is part of the Tramandaí hydrographic system, which flows to the Atlantic Ocean. The headwaters of the Maquiné River are situated in Planalto Basáltico (a basaltic plateau; elevation $\approx 1,000 \mathrm{~m}$ a.s.1.) draining the Atlantic slope of the Serra Geral down to Lake Quadros, in the coastal plain $(<10 \mathrm{~m}$ a.s.l.). Regional climate is humid subtropical (Köppen's Cfa; Moreno, 1961), with mean temperatures above $22^{\circ} \mathrm{C}$ in the warmest month, and between 13 and $15^{\circ} \mathrm{C}$ in the coldest (July) (Nimer, 1990). Mean annual temperature is around $18^{\circ} \mathrm{C}$. There is no typical dry season and annual rainfall is high (1400-1800 mm), with elevated frequency of rainy days throughout the year (Hasenack \& Ferraro, 1989; Nimer, 1990). 
The region of the Maquiné river basin corresponds to the southern limit of the Atlantic Forest distribution (dense ombrophilous forest). From this area to the south and west, the dense ombrophilous forest is replaced by seasonal semideciduous forest (Teixeira et al., 1986). The natural vegetation in the Maquiné basin is formed mainly by dense ombrophilous forest, because of its location in a phytogeographic ecotone, elements of seasonal semideciduous forest can also be found (Sevegnani \& Baptista, 1996). Significant areas of mixed ombrophilous forest (Araucaria Forest) and natural grasslands are other relevant formations in the highest portions of the basin. The dense ombrophilous forest can be further distinguished by four formations: the Lowland Forest (Floresta das Terras Baixas), LowMontane Forest (Floresta Submontana), Montane Forest (Floresta Montana) and High-Montane Forest (Floresta Alto-Montana) (Teixeira et al., 1986).

\section{MATERIAL AND METHODS}

First, the pre-European colonization scenario of the basin vegetation cover was obtained. This was done by determining the probable original geographic ranges of the main dense ombrophilous forest formations according to their altimetric limits, as described in Teixeira et al. (1986). Also, we classified the basin according to different terrain slopes and established a riparian buffer to examine the land-cover pattern in relation to these features.

We then characterized land cover by classifying Landsat TM 5 data (October 9, 1995) into 9 landcover types (see below). The area (in $\mathrm{km}^{2}$ ) of each land-cover type was calculated and its distribution in relation to potential vegetation zones, landscape slope, and riparian buffer was assessed. In order to evaluate conservation status at the basin scale, we made a reclassification of primary land-cover types into 3 classes according to the anthropogenic alteration degree (low, intermediate, or high) represented in relation to the potential natural vegetation. Further details on methodological procedures are given below.

The landscape slope (\%) map was arrived at using a digital elevation model (DEM), provided by the Centro de Ecologia/UFRGS, based on 1:50,000 topographic maps (20 m spaced altimetric lines, Table 1). Landscape slopes were then grouped into 6 classes (Lani et al., 2000): 0-3\%, 3\%-8\%, 8\%-20\%, 20\%$45 \%, 45 \%-75 \%,>75 \%$.
The original vegetation distribution limits were indirectly determined from altimetric zonation described by Teixeira et al. (1986) and Klein (1990), and also mentioned by Sevegnani (1995) (Table 2). The altitudinal limit for the montane forest was set at $800 \mathrm{~m}$ a.s.l. because in the Maquiné region this approximately indicates the transition between the slopes of the Serra Geral and the basaltic plateau. The typical vegetation formations in the basaltic plateau are mixed ombrophilous forest (Araucaria Forest), native steppic grasslands, and the high montane formation of dense ombrophilous forest (which occurs as a narrow strip along the transition zone referred to above). The high montane and mixed ombrophilous forests were grouped into the general category "Forests $>800$ $\mathrm{m}$ ". This category includes any forest formation situated higher than $800 \mathrm{~m}$ a.s.l.

The land-cover map for October 9, 1995 was obtained from a Landsat TM 5 image. Interpretation of land-cover types was based on unsupervised classification (module ISOCLUST, software Idrisi; Eastman, 1998) using bands 3, 4, and 5. Interpretation and reclassification started with 26 classes, which were progressively regrouped until only 8 land- cover classes were left (late successional-stage forest, intermediate successional-stage forest, shrubs, grasslands, agriculture, bare soil, water, and shadow). Several field trips were made into the Maquiné region to help in identifying land-cover types. These trips were not made with a formal sampling design for ground truthing but rather to subjectively help in reordering the 26 pixel classes into a smaller number of land-cover types. This was done by taking the geographic coordinates of patches that were difficult to interpret in the Landsat image and locating them in the field with a GPS receiver.

The grassland patches were identified using a 1995 Landsat image and then reclassified in two categories according to occurrence either over or under $800 \mathrm{~m}$ altitudes. Grasslands over $800 \mathrm{~m}$ were arbitrarily designated as a separate layer denominated "steppic grasslands" (which are native to the Planalto Basáltico). These were then overlaid on the previously obtained altimetric zonation of the forest formations to produce the final potential vegetation map. Grasslands situated at altitudes under $800 \mathrm{~m}$ were considered non-natural grasslands of anthropogenic origin (agriculture, deforestation, and cattle ranching). 
After reclassification, the final land-cover map for October 10, 1995, included nine land-cover types: late successional-stage forest, intermediate successional-stage forest, shrubs, agriculture, bare soil, water, shadow, grasslands $>800 \mathrm{~m}$, and grasslands $<$ $800 \mathrm{~m}$. The land-cover pattern adjacent to the streams was obtained by extracting a $90 \mathrm{~m}$ wide stream buffer strip from the land-cover classification for the whole basin.

Initially, the description of the land-cover pattern at the Maquiné river basin considered all identified land-cover types in relation to:

(a) distribution of potential natural vegetation;

(b) different terrain-slope classes;

(c) the $90 \mathrm{~m}$ riparian buffer.

Then the primary land-cover types were regrouped into 3 classes, representing different anthropogenic alteration degrees relative to the potential natural vegetation: low degree of alteration (late successional-stage forest), intermediate degree (intermediate successional- stage forest), and high degree of alteration (agriculture, bare soil, grasslands under $800 \mathrm{~m}$, and shrub vegetation). The remaining land-cover types (water, grasslands $>800 \mathrm{~m}$, and shadow) were assembled in the "others" category. It is worth noting that the land-cover type "water" mainly represented sections of the Maquiné River that were wide enough to appear in the Landsat image.

\section{RESULTS}

The results for land-cover classification are presented in Table 3. Approximately $30 \%$ of the Maquiné river basin has very steep slopes (slopes $>$ $45 \%$ ), and about $60 \%$ of the area has slopes steeper than $20 \%$. These values illustrate the degree of topographic heterogeneity present in the basin in association with the abrupt altitudinal gradient between the coastal plain and the Serra Geral. The large proportion of steep terrains implies high erosion potential, but this depends on soil characteristics and vegetation cover (Lani et al., 2000). The less steep terrains are represented by portions of the basaltic plateau, leveled steps on the Serra Geral, slopes, and stream valleys.

TABLE 1

Topographic maps (DSG/Ministério do Exército) used for obtaining spatial data on the Maquiné river basin (RS, Brazil).

\begin{tabular}{|c|c|c|c|}
\hline Map sheet & Index map & Scale & Name \\
\hline SH-22-X-C-V-1 & $2972 / 1$ & $1: 50,000$ & Barra do Ouro \\
\hline SH-22-X-C-V-2 & $2972 / 2$ & $1: 50,000$ & Maquiné \\
\hline SH-22-X-C-V-4 & $2972 / 4$ & $1: 50,000$ & Tramandaí \\
\hline SH-22-X-C-II-3 & $2955 / 3$ & $1: 50,000$ & Tainhas \\
\hline SH-22-X-C-II-4 & $2955 / 4$ & $1: 50,000$ & Aratinga \\
\hline
\end{tabular}

TABLE 2

Altimetric ranges used to define the spatial limits of potential vegetation types in the Maquiné river basin (RS, Brazil). MOF $=$ Mixed Ombrophilous Forest; DOF $=$ Dense Ombrophilous Forest. See text for further details.

\begin{tabular}{|l|c|}
\hline \multicolumn{1}{|c|}{ Vegetation type } & Altimetric range (a.s.l.) \\
\hline Lowland Forest & 5 to $30 \mathrm{~m}$ \\
\hline Low-Montane Forest & 30 to $400 \mathrm{~m}$ \\
\hline Montane Forest & 400 to $800 \mathrm{~m}$ \\
\hline Forests $>800 \mathrm{~m}(\mathrm{MOF}+$ High-Montane DOF) & $>800 \mathrm{~m}$ \\
\hline Natural grasslands & $>800 \mathrm{~m}$ \\
\hline
\end{tabular}


TABLE 3

Estimated areas $\left(\mathrm{km}^{2}\right)$ for different land cover types in the Maquiné river basin, RS (October 1995). Results are shown separately for terrain slope (\%) range, potential vegetation zones, and $90 \mathrm{~m}$ riparian buffer. IntFor $=$ forest formation in intermediate successional stages; LateFor $=$ forest formation in late successional stages; grassl $=$ grasslands

\begin{tabular}{|c|c|c|c|c|c|c|c|c|c|c|c|}
\hline & Basin total & IntFor & Shrub & LateFor & Agr & Water & $\begin{array}{c}\text { Grassl }< \\
800 \text { m }^{*}\end{array}$ & Bare soil & Shadow & $\begin{array}{l}\text { Grassl > } \\
800 \text { m }^{* * *}\end{array}$ & Total \\
\hline \multirow{4}{*}{$\begin{array}{l}\text { Slope } \\
\text { classes }\end{array}$} & $0-3 \%$ & 9.9 & 21.3 & 6.4 & 15.5 & 1.0 & 1.1 & 1.7 & 2.2 & 19.5 & 78.6 \\
\hline & $8 \%-20 \%$ & 31.5 & 23.6 & 18.9 & 8.8 & 0.0 & 1.4 & 0.5 & 1.6 & 6.3 & 92.6 \\
\hline & $20 \%-45 \%$ & 68.4 & 33.1 & 34.4 & 14.4 & 0.0 & 1.4 & 0.5 & 3.8 & 0.8 & 156.8 \\
\hline & Total & 191.5 & 121.2 & 111.4 & 57.0 & 1.2 & 5.0 & 3.7 & 20.8 & 38.7 & 550.5 \\
\hline \multirow{3}{*}{$\begin{array}{l}\text { Vegetation } \\
\text { zones }\end{array}$} & Lowland Forest & 5.3 & 11.3 & 1.1 & 13.4 & 1.0 & 1.3 & 0.9 & 1.5 & & 35.7 \\
\hline & Low-Montane Forest & 72.6 & 47.6 & 25.3 & 28.9 & 0.02 & 3.3 & 1.0 & 3.4 & & 182.1 \\
\hline & Montane Forest & 63.9 & 26.7 & 38.8 & 9.5 & 0.1 & 0.5 & 0.1 & 11.3 & & 150.9 \\
\hline \multirow{5}{*}{$\begin{array}{c}\text { Riparian } \\
\text { buffer }(90 \mathrm{~m})\end{array}$} & Low-Montane Forest & 16.24 & 12.25 & 5.19 & 7.87 & 0.00 & 0.53 & 0.31 & 0.84 & & 43.2 \\
\hline & Montane Forest & 11.19 & 4.54 & 6.68 & 1.54 & 0.07 & 0.03 & 0.01 & 3.53 & & 27.6 \\
\hline & Forests $>800 \mathrm{~m}$ & 4.74 & 6.70 & 7.22 & 0.59 & 0.00 & 0.28 & & 1.39 & & 20.9 \\
\hline & Natural grasslands & & & & & & & & & 8.88 & 8.9 \\
\hline & Total & 34.08 & 26.93 & 19.58 & 13.54 & 0.84 & 0.89 & 0.84 & 6.79 & 8.88 & 112.4 \\
\hline
\end{tabular}

* Grasslands originated by human activities.

** Natural grasslands.

According to the potential vegetation zones indirectly obtained from the altitudinal parameters (Fig. 1), before European colonization approximately $93 \%\left(511.8 \mathrm{~km}^{2}\right)$ of the Maquiné basin was covered by forest formations, while only about $7 \%$ was so by natural grasslands ( $>800 \mathrm{~m}$ altitude) (percentage areas calculated from Table 3 ). The Lowland Forest represented about $6.5 \%\left(35 \mathrm{~km}^{2}\right)$ of the total forested area, $33.1 \%\left(182.1 \mathrm{~km}^{2}\right)$ of the basin was covered by Low-Montane Forest, $27.4 \%\left(150.9 \mathrm{~km}^{2}\right)$ was covered by Montane Forest, and 26\% $\left(143 \mathrm{~km}^{2}\right)$ was forest formation at altitudes exceeding $800 \mathrm{~m}$ (Table 2). The $90 \mathrm{~m}$ riparian buffer corresponded to $20.4 \%$ of the study area.

Interpretation of the Landsat image and posterior analysis (grassland reclassification) allowed identification of nine land-cover types (Table 3), represented as percentages in Fig. 2a. The land-use category labeled "late successional-stage forest" includes well-developed forest vegetation (primary or secondary), while "intermediate stage forest" includes less developed secondary forest. The "shrub" category includes vegetation in early successional stages (capoeira, capoeirinha) typical of recently abandoned agricultural fields (Teixeira $e t$ al., 1986). The category "shadow" comprised unidentifiable areas due to shadowing by high valley walls. Land-use types (agriculture, shrub, and secondary forest) affected by human activity cover most of the basin (Fig. 2a). The largest proportion of the total area is covered by secondary forest in several successional stages, particularly early and intermediate, and only about $20 \%$ is covered by secondary or primary forest in the late- successional stage. A small proportion (10.4\%) of the total area was identified as being used for agriculture. However, a large part of the "shrub" category probably includes sites intermittently used by slashand-burn agriculture. For this reason, the proportion of the Maquiné basin actually used for agriculture may reach $32.4 \%$ (or $33.9 \%$, if bare soil and anthropogenic grasslands are included). 


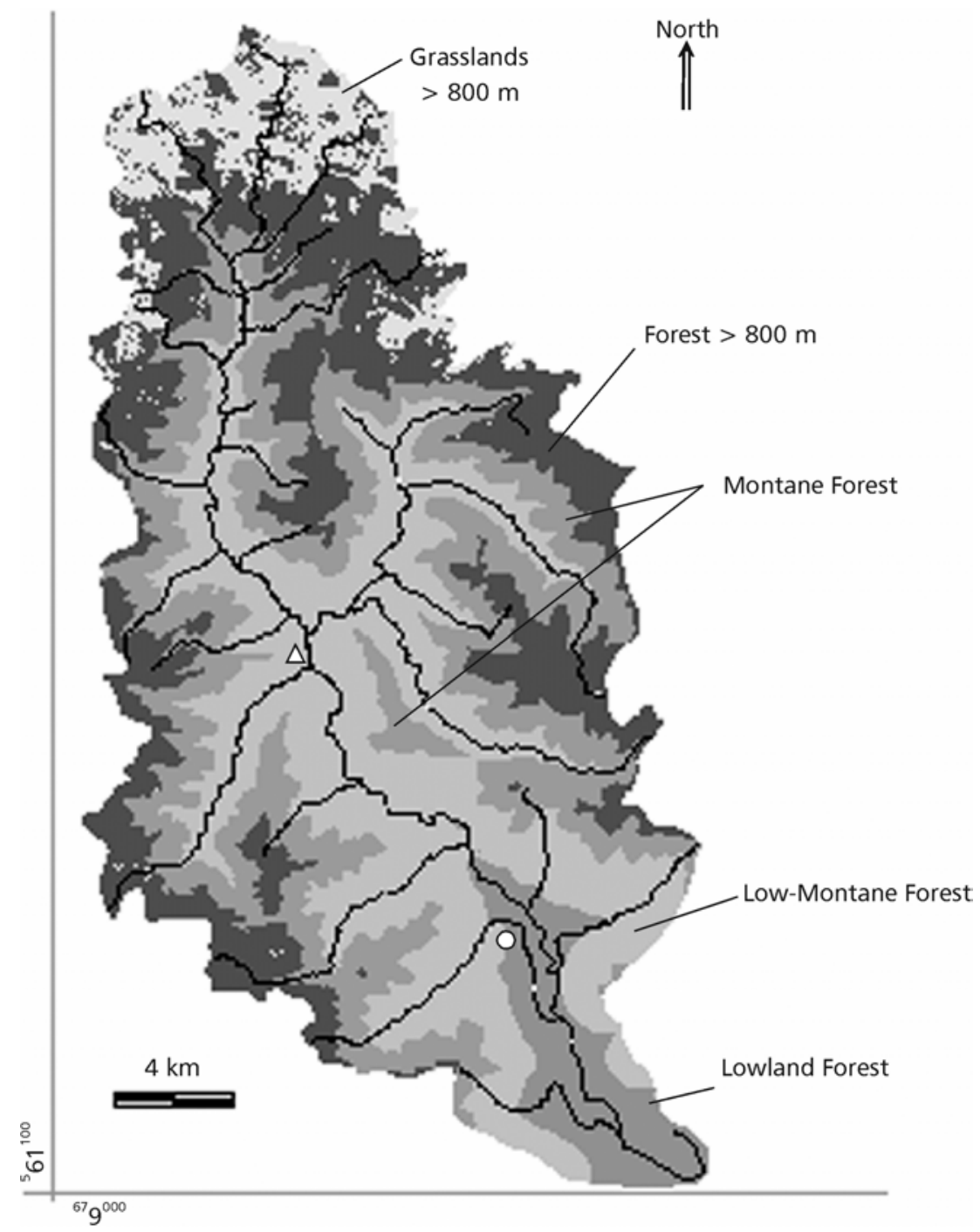

Fig. 1 - Potential natural vegetation in the Maquiné river basin (RS, Brazil), based on altimetric ranges described in Teixeira et al. (1996). Open circle represents the town of Maquiné, open triangle represents the district of Barra do Ouro. Irregular dark lines represent the main streams. Geographic coordinates are shown in the UTM projection system.

The nine primary land-cover categories were reclassified into three classes in order to determine more clearly the anthropogenic alteration degree of the original vegetation cover in the basin (Table 4). These classes indicate the difference between the land cover in 1995 and the one to be expected in the absence of contemporary anthropogenic influence. Only $20.2 \%$ of the study area can be regarded as being in a "low alteration condition", while $34.8 \%$ and $33.9 \%$ represent "intermediate" and "high alteration" states (Fig. 2b). The grassland areas identified in the basaltic plateau do not necessarily represent the original natural grassland distribution and configuration in the region. This is because we did not distinguish between natural grasslands and those originated by deforestation 
or between grasslands and some types of agriculture in the plateau, or between different degradation states of natural grasslands. This is also the reason why grassland areas in the basaltic plateau were assigned to the "others" category and not to one of the three categories expressing degree of anthropogenic alteration.

Fig. 3a shows that the largest proportion of highly altered land cover is on flat terrain (about $50 \%$ of which presents a high degree of anthropogenic alteration). On the other hand, this terrain presents the smallest proportion of less altered land cover (less than $10 \%$ is forest in late successional stage). The highly altered areas occur mainly in the lower valleys of the Maquiné River and its main tributary streams, where agricultural use is intensive (Gerhardt et al., 2000). The percentage of highly altered land cover decreases as the terrains get steeper (Fig. 3a), but the percentage of less altered areas does not increase proportionally. Instead, there is a proportional increase of area occupied by secondary vegetation in intermediate successional stages. This pattern suggests that over the years agriculture activity has concentrated in the more accessible and manageable areas (lowlands and less steep terrains), while those less accessible and manageable were gradually abandoned, favoring the progressive development of secondary vegetation.

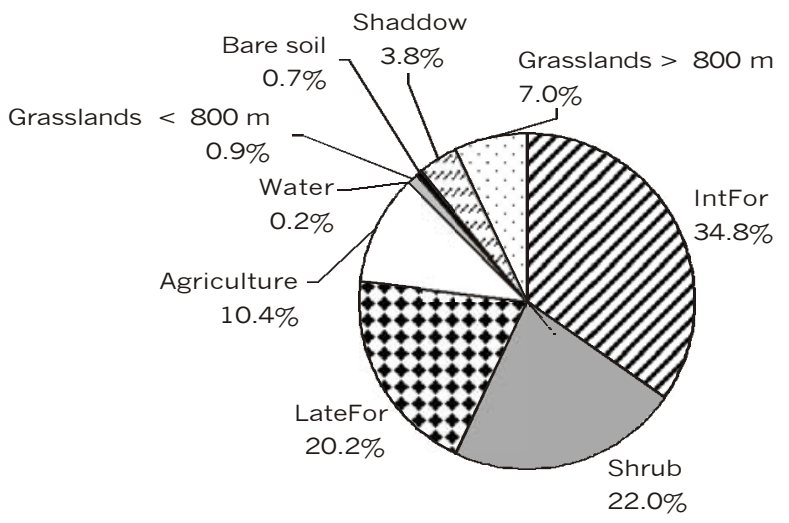

(a) Land cover types

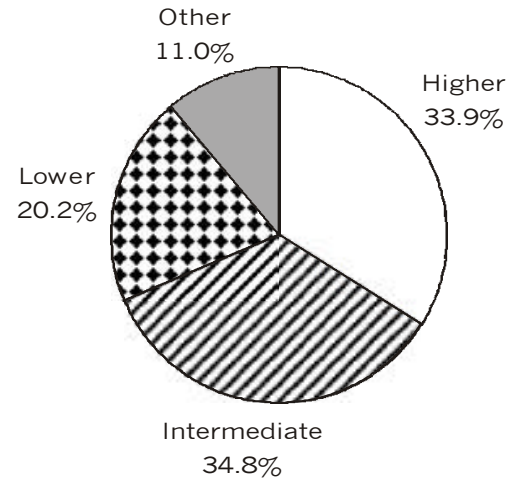

(b) Degree of anthropogenic alteration

Fig. 2 - (a) Relative area (\%) of land-cover types in the Maquiné river basin (RS, Brazil); (b) relative area (\%) of land-cover types reclassified according to degree of anthropogenic alteration in the Maquiné river basin. Data for October 1995. IntFor = secondary forest in intermediate successional stages; LateFor = primary forest or secondary forest in advanced successional state. 
TABLE 4

Estimated areas $\left(\mathrm{km}^{2}\right)$ for different land cover types reclassified according to degree of anthropogenic alteration in the Maquiné river basin, (RS, Brazil) (October 1995). Results are shown separately for terrain slope (\%) range, potential vegetation zones, and $90 \mathrm{~m}$ riparian buffer. High degree of anthropogenic alteration $=$ agriculture, bare soil, shrubs, and grasslands in altitudes under $800 \mathrm{~m}$; intermediate degree of anthropogenic alteration = secondary forest at intermediate successional stages; low degree of anthropogenic alteration = primary or secondary forest in late successional stages; other $=$ shadow, water, and grasslands $<800 \mathrm{~m}$.

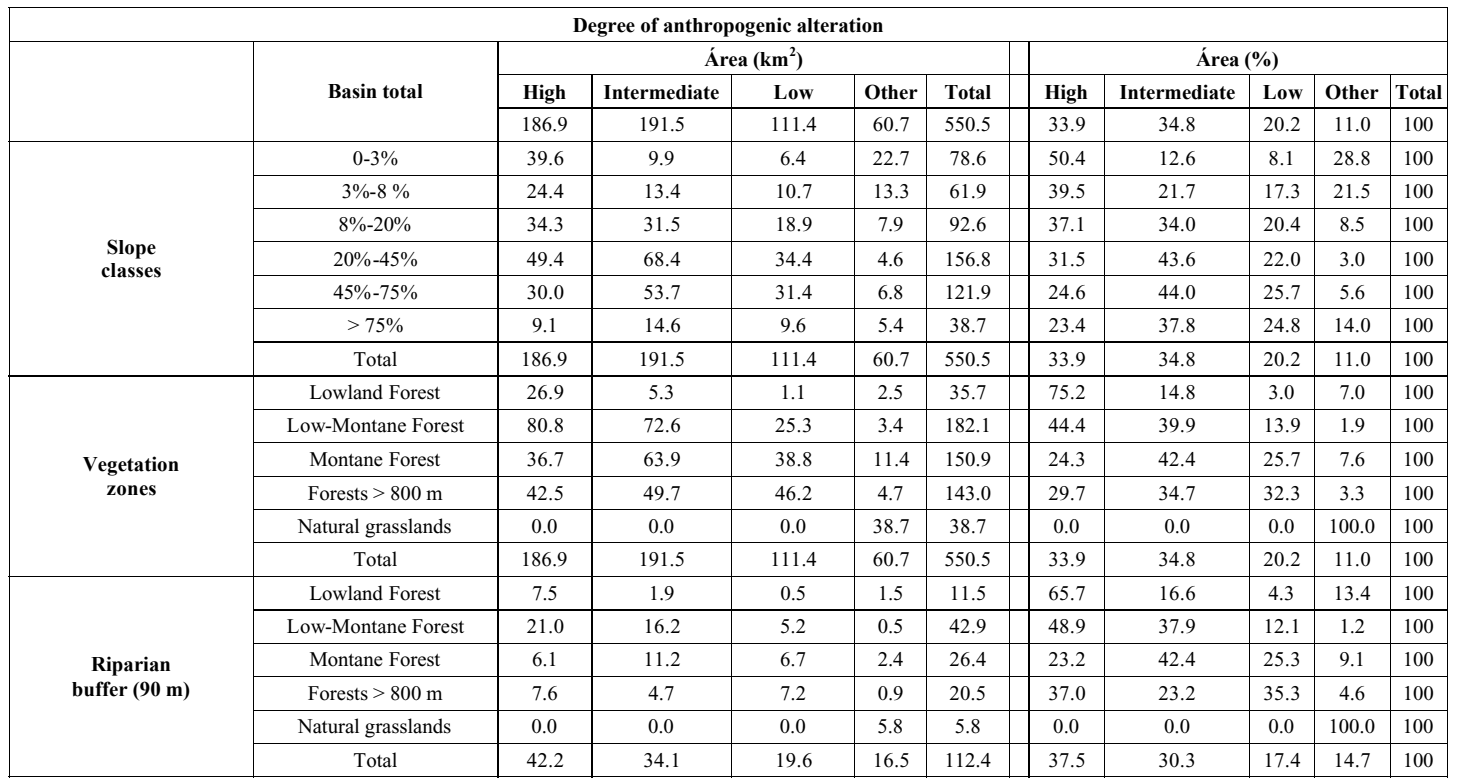

Fig. 3b shows a comparison of the 1995 land cover pattern with the estimated pre-European land cover. If no anthropogenic alteration had occurred, in this figure we would expect $100 \%$ of each column (vegetation zone) to be occupied by land cover classified as "low alteration". The lowland forest is the most degraded formation, with only $3 \%\left(1.1 \mathrm{~km}^{2}\right)$ of the estimated original area $(35.7$ $\mathrm{km}^{2}$ ) still subsisting in a "low alteration" state, and approximately $75 \%\left(26.9 \mathrm{~km}^{2}\right)$ classified as in "high alteration" state. The largest proportions of remnant "late successional-stage forest" (low alteration state) occur in the range of the "Montane Forest" and "forests $>800 \mathrm{~m}$ " (26.7\% and $32.3 \%$, respectively). The results also indicate that land cover in the lowmontane forest range is considerably altered, with more than $40 \%$ of its original area identified as in "high alteration" condition.

Similarly to what was observed for land-cover characteristics in relation to landscape slope, it seems evident that the vegetation is undergoing a recovery process in less accessible areas (decrease in proportional "high alteration" area from lowland forests to montane forests in Fig. 3b). These areas correspond to montane forest and part of the forests $>800 \mathrm{~m}$. The recovery process is characterized by a high proportion of secondary vegetation in intermediate successional stages in the range of the lower-montane (altitudes between 30-400 m) and montane (altitudes between 400-800 $\mathrm{m})$, which is an indication that these areas were more degraded in the past.

The anthropogenic alteration pattern in the 90 $\mathrm{m}$ wide riparian strip (Fig. 3c) is very similar to the pattern observed for the whole basin (Fig. 3b). This was also the case for a $60 \mathrm{~m}$ wide riparian buffer (results not shown). If both "high" and "intermediate" degrees of anthropogenic alteration are considered, approximately $76 \%$ of the total riparian area can be deduced to have been altered.

Fig. 3 presents the joint percentage of "high alteration" and "intermediate alteration" land-cover 
classes, which is extremely important information because it indicates the proportion of the total basin area that has been more intensively (or recently) altered by human activity. Fig. $3 \mathrm{~b}$ reveals that between $65 \%$ (forests $>800 \mathrm{~m}$ altitude) and $90 \%$ (lowland forest) is, or has at some time been, considerably altered in comparison to the pre-European colonization period.

\section{DISCUSSION}

Making maps and ecological zonations based on remotely sensed (e.g., Landsat images) and secondary data (the DSG/Ministério do Exército topographic maps) includes several analytic steps and subjective decisions, with unavoidable presence of some error and imprecision in the results. A few comments are necessary on potential vegetation mapping and land-cover class identification, particularly with regard to separation of forest formations in different successional stages. In the first case, altimetric values from the literature (Teixeira et al., 1986) were used as the spatial limits of each forest formation within the Maquiné river basin. This means that an unrealistically precise boundary was used to represent the transition between each forest formation. At the ground scale, this transition is not precise or abrupt, and may occur at slightly different altitudes. For this reason, the potential vegetation estimates must be viewed cautiously and only for comparative purposes.

Regarding land-cover classification, it was difficult to distinguish forest formations in different successional stages (e.g., mature or late successional stages from intermediate stages, or early successional stages from agriculture). This problem was probably due to the influence of heterogeneous topography on the land-cover spectral response, as well as to the high heterogeneity of the vegetation. The present land cover in the Serra Geral region is extremely variable and fragmented (Jarenkow, 1994; Sevegnani, 1995) and may be described as a mosaic of agriculture and primary and secondary vegetation in several sucessional stages. Even the primary or old secondary forests have remarkable spatial variation in size and physical structure. These differences are related to the altitudinal gradient, soil conditions, and terrain slope at the local scale (Mantovani, 1990; Mantovani et al., 1990), as well as to different exposures to regionally dominant air masses (Klein,
1980) and to differences in the hill slope position in relation to the sun. This latter aspect was apparent in both the Landsat image and field observations. The position in relation to the sun is the main reason why the northward and southward slopes are "almost always ecologically different" (Forman, 1995). In the Southern Hemisphere, northward slopes are more exposed to the sun and receive more energy per unit area than southward slopes, which also explains why agricultural activities are usually more intense on northward hill slopes.

An additional factor causing land cover heterogeneity in the Maquiné basin is the system of land ownership and agricultural land use, which is typically characterized by small land tracts and slash-and-burn agriculture. In this system, a land tract is exploited for some time, then abandoned for a few years and used again, and so on. Therefore, secondary vegetation patches originating in abandoned fields tend to have small total areas, particularly on steeper hill slopes (Gerhardt et al., 2000), which implies wide variation in the age and successional stage of the vegetation stands. For this reason, a simple, generalized landcover classification was used in the present work. Formal ground truthing and assessment of classification precision are recommended if a more detailed result is desired (e.g., SOS Mata Atlântica et al., 1998).

The results presented here, while evidencing a recovery process currently underway in the vegetation, indicate that the natural vegetation cover of the Maquiné river basin has been highly degraded in the past, as approximately $70 \%$ of its area was shown to be covered by vegetation classified as highly or intermediately altered relative to the potential natural vegetation. These results clearly relate to the history of colonization and agricultural exploitation in the region. Degradation of the natural vegetation cover of the Maquiné region was a fast process begun at the end of the nineteenth century when the first European settlers arrived. Deforestation in the region and in Rio Grande do Sul was more intense between 1940 and 1960 (Gerhardt et al., 2000; SOS Mata Atlântica et al., 1998). During this period the relative area of forest ecosystems in Rio Grande do Sul State decreased from 35.08\% to 9.57\% (SOS Mata Atlântica et al., 1998). After 1960-70, the decrease in productivity and the modernization of agricultural techniques led to a decline in the rural population and a corresponding movement towards urban centers (Gerhardt et al., 2000). 
(a)

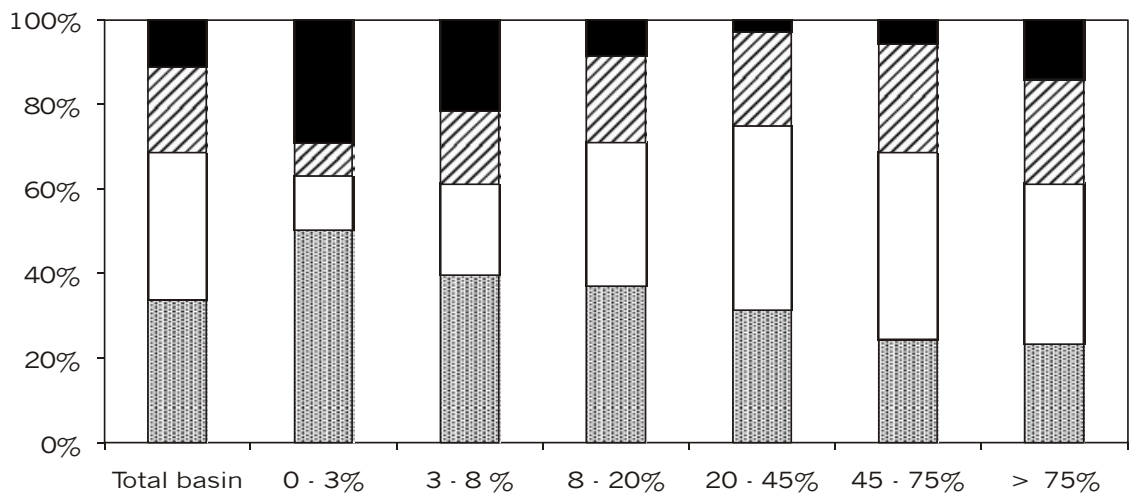

(b)

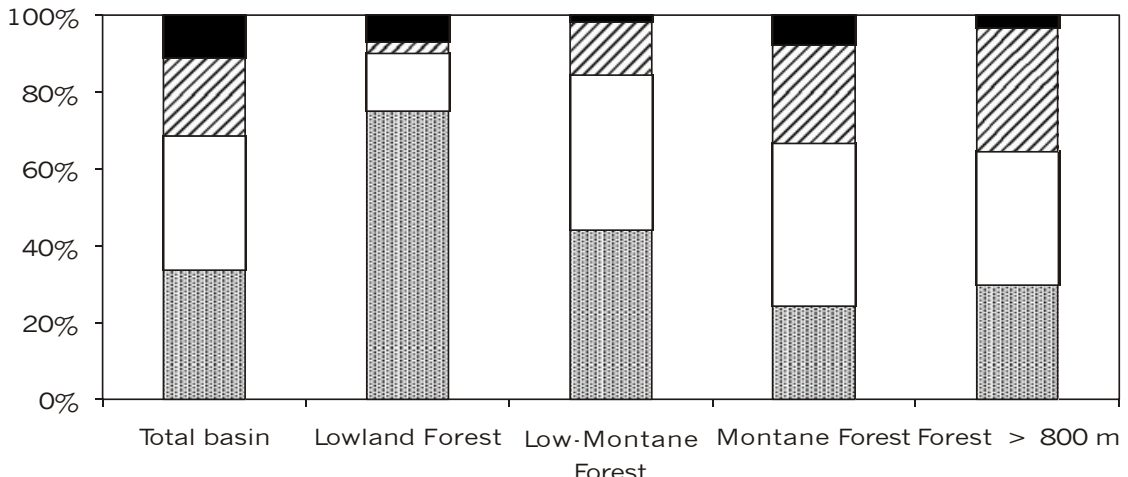

(c)

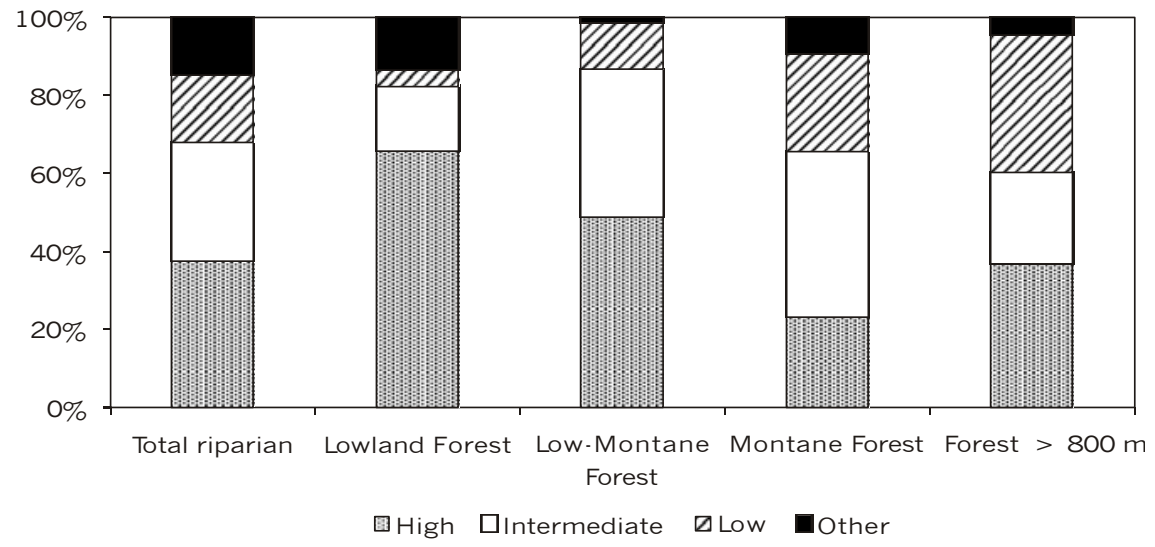

Fig. 3 - Relative area (\%) occupied by land-cover classes representing different degrees of anthropogenic alteration in the Maquiné river basin (RS, Brazil): (a) in each class of terrain slope, (b) in each vegetation zone, (c) in a $90 \mathrm{~m}$ wide riparian buffer and in each vegetation zone. 
The results of the current study provide indirect evidence that the first lands to be abandoned were those in more remote and less arable or productive areas in the hill slopes of the Serra Geral, while the plain lowlands in the valleys are still intensively used agriculturally. This process may be inferred from Fig. 3 , which can be regarded as a snapshot representation of the land-cover pattern in 1995. As most of the basin's original vegetation was replaced by agriculture in the past, the different degrees of anthropogenic alteration of the present vegetation cover may also be interpreted as indicators of the time elapsed since the agricultural areas were abandoned. Thus, a lower degree of alteration means that the vegetation is either primary forest or late successional-stage secondary forest, which in turn indicates that a numerous decades have passed since land management for agriculture ceased. The reverse is valid for land-cover types representing "high alteration" (agriculture, non-natural grasslands, bare soil, and shrubs). Consequently, the progressive decrease in the proportion of highly altered land cover occurring in the direction of the steeper hill slopes (Fig. 3a) and from Lowland Forests to Montane Forest (Fig. $3 \mathrm{~b}$ ) is also a historical record of the land abandonment process.

The proportionately large area covered by secondary forest in intermediate successional stages indicates that the vegetation cover of the basin was in better condition in 1995 than it had been a few decades before, indicating a trend towards forest formation recovery. However, SOS Mata Atlântica et al. (1998) indicated a 5.38\% decrease in the area of forest formations in advanced successional stages for Rio Grande do Sul State and a 3.3\% decrease within the limits of the larger region that includes the Maquiné basin (1:250,000 scale Gravataí map sheet of the DSG/Ministério do Exército). These results indicate that the regional trend seems to be different from that in the Maquiné basin and, consequently, the results obtained in the present work cannot be extrapolated to other areas. The results of SOS Mata Atlântica et al. (1998) also show that only $4.92 \%$ of the original forest formation area in Rio Grande do Sul existed in 1995 as forest patches in advanced successional stages. As shown in Fig. 2, 20.2\% of the land cover in the Maquiné river basin is represented by forest formation in advanced successional stages. Therefore, in spite of the high degree of land cover alteration in the past, this area may be considered important for Atlantic Forest conservation in Rio Grande do Sul.
The significance of the Maquiné basin for conservation is also related to its geographic location in the southern limit of dense ombrophilous forest, implying that the region constitutes the southern limit of several animal and plant species (see Bencke \& Kindel, 1999) and has a high potential for endemic species occurrence. The importance of this region as an area of fish endemism has already been recognized (CIB et al., 2000; Reis \& Cardoso, 2001, and references therein) and CIB et al. (2000) judged it to be of "high biological importance" for birds and of "extreme biological importance" for plants.

The reclassification of land-cover classes according to the degree of anthropogenic alteration is particularly useful when the objective is to compare different sites, or to assess the present conservation state in relation to a better, but not directly measurable, past condition (e.g., Edgar et al., 2000). In the present study, however, the conservation state of the Atlantic Forest was assessed only on the basis of relative areas occupied by different land cover types, and particularly considering the successional stage of secondary vegetation as inferred from satellite imagery data interpretation. It is assumed that secondary forest in late successional stages presents a better condition when compared to secondary forest in intermediate or early successional stages. The ecological integrity (see De Leo \& Levin, 1997, for a review of the concept) at a more detailed scale was not assessed, as other criteria would have to be taken into account (floristic composition, species richness, endemics, functional groups, phytosociological features, etc.). Ecological integrity (see De Leo \& Levin, 1997, for a review), a concept useful in establishing ecological conservation and restoration goals (Angermeier \& Karr, 1994; Carrol \& Meffe, 1997), considers complete native biological diversity (genes, populations, species, communities, and ecosystems) and the patterns and processes that create and support diversity in a given region (Carrol \& Meffe, 1997). In the Maquiné basin, because large areas of natural vegetation have been replaced by agriculture in the past, some regionally characteristic elements, patterns, and processes may have disappeared or been largely altered. This is especially relevant for the Lowland Forests (almost completely eliminated from the Maquiné basin, Table 3) and Sub-montane Forests, which are presently severely degraded throughout their natural distribution range (Waechter, 1985; Teixeira et al., 1986; Bencke \& Kindel, 1999). 
The magnitude of land cover alteration in the Maquiné river basin may also have had an important influence on the structure and function of its stream ecosystems. The effects of watershed deforestation on aquatic habitats and biota are well known (Hanchet, 1990; Allan et al., 1997; Johnson et al., 1997; Tucci \& Clarke, 1997; Harding et al., 1998), and riparian areas are particularly relevant elements (Rodrigues \& Leitão Filho, 2000). Such environments can be regarded as a mosaic of diverse habitat types and their associated biota (Gregory et al., 1991; Rodrigues \& Leitão Filho, 2000) not only because they are lateral ecotones between aquatic and terrestrial systems, but also because their features vary longitudinally along the rivers and depend on regionally dominant phytogeographic formations. Such environmental heterogeneity complicates adoption of standard terminology and classifications (Rodrigues \& Leitão Filho, 2000; Ward \& Wiens, 2001). Clearly, different approaches will lead to different sizes and scales for setting the spatial limits of a riparian environment. Large \& Petts (1992) review several riparian buffer widths, recommended for different purposes, with values ranging between $2 \mathrm{~m}$ (to control nitrate fluxes) to $200 \mathrm{~m}$ (to function as corridors for vertebrate species). The $90 \mathrm{~m}$ wide riparian buffer used in the present study was set mainly because of the resolution of Landsat TM data (30 $\mathrm{m}$ pixels). Nevertheless, it is also reasonable that the riparian buffer should be defined in view of multiple conservation objectives. These include the provision of habitats for riparian species, increase of habitat diversity in the basin, maintenance of forest habitat connectivity across the basin, aquatic habitat protection, and improvement of the aesthetic value or viability of the agroforestry system (Large \& Petts, 1992; Forman, 1995).

In the Maquiné river basin, the pattern of land cover alteration in the riparian zone is similar to that of the whole basin (Fig. 3). This means that riparian areas present a progressively worse condition as they approach the lower stream valleys, and that about $70 \%$ of the original riparian cover has been altered since the early nineteenth century (Fig. 3c). Consequently, riparian areas (especially along the lower portions of stream valleys) should be particularly considered for restoration if they constitute important conservation strategy elements. Apart from protecting aquatic habitats, they may be particularly important in improving connectivity between terrestrial habitats. In the Maquiné basin, most patches of late successional-stage forest vegetation are not isolated fragments, but "older" patches in a matrix of secondary vegetation in earlier successional stages. This presents a good opportunity for management action to enhance terrestrial habitat connectivity.

Other interesting prospective aspects for research and conservation management emerging during this study were the need for (a) locating the most significant patches of primary or mature secondary vegetation; (b) determining regional parameters for assessing changes (increase or decrease) in Atlantic Forest ecological integrity; and (c) creating a strategy for connectivity enhancement at the ecoregional scale by taking advantage of the several regional conservation units (Reserva Biológica da Serra Geral, Centro de Pesquisas Pró-Mata, APA Rota do Sol, Floresta Nacional de São Francisco de Paula, Parque Estadual de Tainhas, and Reserva Biológica Estadual Mata Paludosa). These areas are especially important for research because they probably represent the least degraded Atlantic Forest areas in the region.

Acknowledgements - We are grateful to Carlos Sarmento and William Wazlavik for helping in field and laboratory work, and to Demétrio Guadagnin, José S. R. Pires, José R. Verani, and Odete Rocha for critical suggestions on the manuscript. This research was supported by CAPES and USAID/WWF.

\section{REFERENCES}

ALLAN, J. D., ERICKSON, D. L. \& FAY, J., 1997, The influence of catchment land use on stream integrity across multiple spatial scales. Freshwat. Biol., 37: 149-161.

ANGERMEIER, P. L. \& KARR, J. R., 1994, Biological integrity versus biological diversity as policy directives: protecting biotic resources. Bioscience, 44: 690-697.

BENCKE, G. A. \& KINDEL, A., 1999, Bird counts along an altitudinal gradient of Atlantic forest in northeastern Rio Grande do Sul, Brazil. Ararajuba, 7: 91-107.

CÂMARA, I. G. (org.)., 1991, Mata Atlântica. Editora Index/ SOS Mata Atlântica/Fundação Banco do Brasil, Rio de Janeiro.

CARROL, C. R. \& MEFFE, G. K., 1997, Management to meet conservation goals: general principles, Chap. 4, pp. 347384. In: G. K. Meffe \& C. R. Carrol (eds.), Principles of conservaton biology. 2. ed. Sinauer Assoc., Sunderland.

CIB - CONSERVATION INTERNATIONAL DO BRASIL, FUNDAÇÃO SOS MATA ATLÂNTICA, FUNDAÇÃO BIODIVERSITAS, INSTITUTO DE PESQUISAS ECOLÓGICAS, SECRETARIA DO MEIO AMBIENTE DO ESTADO DE SÃO PAULO \& SEMAD/INSTITUTO ESTADUAL DE FLORESTAS, MG, 2000, Avaliação e ações prioritárias para a conservação da biodiversidade da Mata Atlântica e Campos Sulinos. Ministério do Meio Ambiente/SBF, Brasília, 40p. 
DE LEO, G. A. \& LEVIN, S., 1997, The multifaceted aspects of ecosystem integrity. Conservation Ecology [on line], l(1). Disponível em: http://www.consecol.org/vol11/iss1/art3.

EASTMAN, J. R., 1998, Idrisi for Windows, versão 2. Manual do Usuário: Introdução e Exercícios Tutorais. H. Hasenack \& E. Weber (eds.), UFRGS/Centro de Recursos Idrisi, Porto Alegre, 235p.

EDGAR, G. J., BARRET, N. S., GRADDON, D. J. \& LAST, P. R., 2000, The conservation significance of estuaries: a classification of Tasmanian estuaries using ecological, physical and demographic attributes as a case study. Biological Conservation, 92: 383-397.

EHLERS, M., 1996, Remote Sensing and Geographic Information Systems: advanced technologies for environmental monitoring and management, pp. 17-25. In: V. H. Singroy, D. D. Nebert \& A. I. Johnson (eds.), Remote sensing and GIS for site characterization: applications and standards. ASTM STP, West Conshohocken.

FEPAM - FUNDAÇÃO ESTADUAL DE PROTEÇÃO AMBIENTAL DO ESTADO DO RIO GRANDE DO SUL, 2000, Diretrizes ambientais para o desenvolvimento dos municípios do Litoral Norte. Cadernos de Planejamento e Gestão Ambiental, n. 1. Secretaria Estadual do Meio Ambiente/RS, Porto Alegre, 95p.

FORMAN, R. T. T., 1995, Landscape mosaics. The ecology of landscapes and regions. Cambridge University Press, Cambridge, 632p.

GERHARDT, C. H., TROIAN, L. C., GUTERREZ, L. M., MAGALHÃES, R. G., GUIMARÃES, L. A., FERREIRA, L. O. \& MIGUEL, L. A., 2000, Caracterização do meio rural do municipio de Maquiné, RS: subsídios para um desenvolvimento rural sustentável. Relatório PROPESq/ UFRGS, Porto Alegre, 57p.

GREGORY, S. V., SWANSON, F. J., MCKEE, W. A. \& CUMMINS, K. W., 1991, An ecosystem perspective of riparian zones. Bioscience, 41: 540-551.

HANCHET, S. M., 1990, Effect of land use on the distribution and abundance of native fish in tributaries of the Waikato River in the Hakarimata Range, North Island, New Zealand. N. Z. J. Mar. Freshwat. Res., 24: 159-171.

HARDING, J. S., BENFIELD, E. F., BOLSTAD, P. V., HELFMAN, G. S. \& JONES, B. D., 1998, Stream biodiversity: the ghost of land use past. Proc. Nat Acad. Sci. USA, 95: 14843-14847.

HASENACK, H. \& FERRARO, L. W., 1989, Considerações sobre o clima da região de Tramandaí - RS. Pesquisas, 22: 53-70.

JARENKOW, J. A., 1994, Estudo fitossociológico comparativo entre duas áreas com mata de encosta no Rio Grande do Sul. Tese de Doutorado, Programa de Pós-graduação em Ecologia e Recursos Naturais, Universidade Federal de São Carlos, $125 \mathrm{p}$

JOHNSON, L. B., RICHARDS, C., HOST, G. E. \& ARTHUR, J. W., 1997, Landscape influences on water chemistry in midwestern stream ecosystems. Freshwat. Biol., 37: 193-208.

JOHNSTON, C. A., 1998, Geographic Informations Systems in ecology. Blackwell Science Ltd., Oxford, 239p.
KLEIN, R. M., 1980, Ecologia da flora e vegetação do Vale do Itajaí. Sellowia, 32: 165-389.

KLEIN, R. M., 1990, Estrutura, composição florística, dinamismo e manejo da "Mata Atlântica" (Floresta Ombrófila Densa) do sul do Brasil, pp. 259-286. In: ACIESP (ed.), Proceedings of the II Simpósio de Ecossistemas da Costa Sul e Sudeste Brasileira. Estrutura, função e manejo. Águas de Lindóia, São Paulo.

LANI, J. L., RESENDE, M. \& REZENDE, S. B., 2000 Avaliação e ações prioritárias para a conservação da biodiversidade dos biomas Mata Atlântica e Campos Sulinos - fatores abióticos. In: Brasil - Ministério do Meio Ambiente, Avaliação e ações prioritárias para conservação da biodiversidade da Mata Atlântica e Campos Sulinos. Estudos prévios (fase preparatória). MMA, CIB do Brasil, Fund. SOS Mata Atlântica, Fund Biodiversitas, IPE, SEMA-SP de São Paulo, SEMAD/IE F-MG, Brasília. Disponível em: http://conservation.org.br/ $\mathrm{ma} /$.

LARGE, A. R. \& PETTS, G. E., 1992, Rehabilitation of river margins, Chap. 21, pp. 401-418. In: P. Calow \& G. E. Petts, The rivers handbook hydrological and ecological principles. Blackwell Scientific Publications, Oxford.

LIMA, R. N., CAVALHEIRO, F. \& SANTOS, J. E., 1998, Zoneamento ambiental da bacia hidrográfica do rio Una, Guarapari, ES, pp. 609-620. In: Anais do VIII Seminário Regional de Ecologia, v.II. Programa de Pós-graduação em Ecologia e Recursos Naturais, Universidade Federal de São Carlos, São Carlos.

MANTOVANI, W. A., 1990, Dinâmica nas florestas da encosta Atlântica, pp. 304-313. In: ACIESP (ed.), Proceedings of the II Simpósio de Ecossistemas da Costa Sul e Sudeste Brasileira. Estrutura, função e manejo. Águas de Lindóia, São Paulo.

MANTOVANI, W., RODRIGUES, R. R., ROSSI, L., ROMANIUC-NETO, S., CATHARINO, E. L. M. \& CORDEIRO, I., 1990, A vegetação na Serra do Mar em Salesópolis - SP. In: ACIESP (ed.), Proceedings of the II Simpósio de Ecossistemas da Costa Sul e Sudeste Brasileira. Estrutura, função e manejo. Águas de Lindóia, São Paulo.

MARCUZZO, S., PAGEL, S. M. \& CHIAPPETTI, M. I. S., 1998 A reserva da biosfera da Mata Atlântica no Rio Grande do Sul. Situação atual, ações e perspectivas. Conselho Nacional da Reserva da Biosfera da Mata Atlântica, São Paulo, Série Cadernos da Reserva da Biosfera da Mata Atlântica, 60p.

MILLER, K. R., 1997, Em busca de um novo equilibrio: diretrizes para aumentar as oportunidades de conservação da biodiversidade por meio do manejo biorregional. Instituto Brasileiro do Meio Ambiente e dos Recursos Renováveis, Brasília, 94p.

MORENO, J. A., 1961, Clima do Rio Grande do Sul. Secretaria da Agricultura do Estado do Rio Grande do Sul, Porto Alegre, $42 p$.

MYERS, N., MITTERMEIER, R. A., MITTERMEIER, C. G., FONSECA, G. A. B. \& KENT, J., 2000, Biodiversity hotspots for conservation priorities. Nature, 403: 854-858. 
NIMER, E., 1990, Clima, pp. 151-187. In: IBGE, Geografia do Brasil: região Sul. IBGE, Rio de Janeiro.

PEROTTO, M. A., GUERRA, T. \& LEMOS, C. A. (org.), 2000, Proceedings of the I Encontro de Pesquisadores do Vale do Rio Maquiné, 82p. Anama, Departamento de Ecologia/UFRGS, Secretaria Estadual do Meio Ambiente/RS, Porto Alegre.

PINTO, L. P. S., COSTA, J. P. O., FONSECA, G. A. B. \& COSTA, C. M. R., 1996, Mata Atlântica: ciência, conservação e políticas. Workshop científico sobre a Mata Atlântica. Secretaria do Meio Ambiente do Estado de São Paulo, São Paulo. (Documentos Ambientais.)

PIRES, A. M. Z. C. R., SANTOS, J. E. \& PIRES, J. S. R., 1998, Elaboração de um banco de dados digitais georreferenciados para caracterização ambiental de uma unidade de conservação, pp. 585-598. In: Anais do VIII Seminário Regional de Ecologia. V. II. Programa de Pós-graduação em Ecologia e Recursos Naturais, Universidade Federal de São Carlos, São Carlos.

REIS, R. E. \& CARDOSO, A. R., 2001, Two new species of Rineloricaria from southern Santa Catarina and northeastern Rio Grande do Sul, Brazil (Teleostei: Loricariidae). Ichthyological Explorations of Freshwaters, 12: 319-332.

RODRIGUES, R. R. \& LEITÃO FILHO, H. F. (eds.)., 2000, Matas ciliares: conservação e recuperação. Editora da Universidade de São Paulo/FAPESP, São Paulo, 320p.

SAATCHI, S., AGOSTI, D., ALGER, K., DELABIE, J. \&
MUSINSKI, J., 2001, Examining fragmentation and loss of primary forest in the southern Bahian Atlantic forest of Brazil with radar imagery. Conserv. Biol., 15: 867875

SEVEGNANI, L., 1995, Fitossociologia de uma floresta secudária, Maquiné, RS. Dissertação de Mestrado, Instituto de Biociências, Departamento de Botânica, Universidade Federal do Rio Grande do Sul, 148p.

SEVEGNANI, L. \& BAPTISTA, L. R. M., 1996, Composição florística de uma floresta secundária no âmbito da Floresta Atlântica, Maquiné, RS. Sellowia (45-48): 47-71.

SOS MATA ATLÂNTICA, INSTITUTO NACIONAL DE PESQUISAS ESPACIAL \& INSTITUTO SOCIOAMBIENTAL, 1998, Atlas da evolução dos remanescentes florestais e ecossistemas associados no domínio da Mata Atlântica no período 1990-1995. Fundação SOS Mata Attântica, São Paulo, $55 \mathrm{p}$.

TEIXEIRA, M. B., COURA NETO, A. B. \& PASTORE, U. et al., 1986, Vegetação, pp. 541-620. In: IBGE, Levantamento de recursos naturais, Rio de Janeiro, IBGE, v. 33.

TUCCI, C. E. M. \& CLARKE, R. T., 1997, Impacto das mudanças da cobertura vegetal no escoamento: revisão. Revista Brasileira de Recursos Hídricos, 2: 135-152.

WAECHTER, J. L., 1985, Aspectos ecológicos da vegetação de restinga no Rio Grande do Sul. Comun. Mus. Cienc. PUCRS, Sér. Bot., 33: 49-68.

WARD, J. V. \& WIENS, J. A., 2001, Ecotones of riverine ecosystems: role, typology, spatio-temporal dynamics, and river regulation. Ecohydrol. Hydrobiol., 1: 25-36. 